5. Kovalenko, V. P., T. I. Nezhlukchenko, and S. Y. Plotkin. 2008. Suchasni metody otsinky i prohnozuvannya zakonomirnostey ontohenezu tvaryn i ptytsi - Modern methods of assessment and prediction of ontogenesis patterns of animals and birds. Visnyk ahrarnoi nauky - Bulletin of Agrarian Science. 2:40-45 (in Ukrainian).

6. Kolesnyk, N. N. 1985. Genetyka zhyvoj massy skota - Genetics of live weight of cattle. Kyiv, Urozhaj,184 (in Russian).

7. Kovalenko, V. P., S. Yu. Bolelaya, Yu. P. Polupan, and S. Ya. Plotkyn. 1997. Rekomendacii po ispol'zovaniyu osnovnyh selekcioniruemyh priznakov s.-h. zhivotnyh i pticy - The recommendations for using the major selectable features of agricultural animals and poultry. Kherson, 44 (in Russian).

8. Svechyn, K. B. 1976. Individual'noe razvitie zhivotnyh - Individual development of animals. Kyiv, Urozhaj, 287 (in Russian).

9. Cvechyn, Ju. K. 1974. Intensivnost' formyrovanyja y konstytucyja svynej - Intensity of formation and constitution of pigs. Vestnyk sel'skokhozyaystvennoy nauky - Bulletin of Agricultural Science. 10:69-76 (in Russian).

10. Svechyn, Yu. K. 1985. Prognozirovanie produktivnosti zhivotnyh v rannem ontogeneze - The forecasting of animal productivity in the early ontogenesis. Vestnyk sel'skokhozyaystvennoy nauky Bulletin of Agricultural Science. 4:103-108 (in Russian).

11. Topchiy, L. I. 2007. Indeksna otsinka rostu i rozvytku svyney askaniys'koho typu ukrayins'koyi m"yasnoyi porody - An indexed assessment of the growth and development of the Askanian type of Ukrainian meat breed. Visnyk ahrarnoi nauky - Bulletin of Agrarian Science. 9:7576 (in Ukrainian).

УДК 636.92.033.082.2

\title{
РІВЕНЬ ПРОДУКТИВНОСТІ КРОЛІВ РІЗНИХ ПОРІД ТА ЕФЕКТИВНІСТЬ ВИКОРИСТАННЯ СЕЛЕКЦІЙНИХ ІНДЕКСІВ В КРОЛІВНИЦТВІ
}

\section{О. М. ГАВРИШ \\ Черкаська дослідна станція біоресурсів НААН (Черкаси, Україна) bioresurs.ck@ukr.net}

Досліджено рівень продуктивності кролів різних порід в умовах промислової технологіі розведення на базі кролеферм СГ ПП «Марчук Н.В.» та дослідній кролефермі Черкаської дослідної станиії біоресурсів НААН (Черкаська обл.). Встановлено, щуо за показниками живої маси перевагу над аналогами мали кролі новозеландської білої породи. Індекс збитості свідчить про вищу м'ясну продуктивність кролів порід м'ясного напряму селекції новозеландська біла та каліфорнійська, коефіцієнти по групах яких становила 62-66\%, щуо на 6 та 10\% вище аналогічного показника по досліджуваній групі кролів породи полтавське срібло $(P>0,999)$. Показник плідності кролематок піддавався мінливості як всередині досліджуваних популяиій так і поколінь, загалом варіював в межах 8,10-8,30 голів. Використання індексної оцінки тварин та аналіз різних схем їх схрещування, дає змогу стверджувати, щзо максимальні показники живої маси мали нащадки тварин, селекційні індекси яких для самщів становили не нижче 60 балів, самок - 55 балів відповідно, щуо слід враховувати при плануванні селекційної роботи 3 популяціями.

Ключові слова: кролі, жива маса, статі тіла, м'ясна продуктивність відтворювальна здатність, селекційні індекси 


\section{PRODUCTIVITY LEVELS OF DIFFERENT ROAD CROPS AND EFFECTIVENESS OF THE USE OF SELECTIVE INDICES IN ROUGHING}

\section{O. M. Gavrish}

Cherkassy Experimental Station of Bioresources of NAAS (Cherkassy, Ukraine)

The level of productivity of rabbits of different breeds in the conditions of industrial technology of breeding on the basis of the rabbit farm SG PJ "Marchuk NV" and the experimental rabbit farm of Cherkasy research station of bioresources of the National Academy of Sciences (Cherkasy region). It has been established that on the basis of live weight, the New Zealand white rabbits had a superiority over their counterparts. The loss index indicates higher meat productivity of rabbits in the New Zealand White and Californian breeding lines, with coefficients in groups of 62-66\%, which is 6 and 10\% higher than the Poltava silver $(P>0,999)$. Indicator of fertility of the krolatov was subjected to variability both inside the studied populations and generations, in general, varied within 8,10-8,30 heads. The use of the index assessment of animals and the analysis of different patterns of their interbreeding makes it possible to state that the maximum living weight values were descendants of animals whose selection indices for males were not lower than 60 points, females - 55 points, respectively, which should be taken into account when planning selection work with populations .

Keywords: rabbit, live weight, sex body, meat productivity, reproductive ability, breeding indices

\section{УРОВЕНЬ ПРОИЗВОДИТЕЛЬНОСТИ КРОЛИКОВ РАЗНЫХ ПОРОД И ЭФФЕКТИВ- НОСТЬ ИСПОЛЬЗОВАНИЯ СЕЛЕКЦИОННЫХ ИНДЕКСОВ В КРОЛИКОВОДСТВЕ}

\section{А. Н. Гавриш}

Черкасская исследовательская станџия биоресурсов НААН (Черкасы, Украина)

Исследован уровень производительности кроликов разных пород в условиях промышленной технологии разведения на базе кролеферм СГ ПП «Марчук Н.В.» и Черкасской опытной станциии биоресурсов НААН (Черкасская обл.). Установлено, что по показателям живой массы превосходство над аналогами имели кролики новозеландской белой породы. Индекс сбитости свидетельствует о высшей мясной продуктивности кроликов пород мясного направления селекиии новозеландская белая и калифорнийская, коэффициенты, по группам которых составляла 62-66\%, что на 6 и 10\% выше аналогичного показателя по исследуемой группе кроликов породы полтавское серебро (Р > 0,999). Показатель плодовитости крольчих подвергался изменчивости как внутри исследуемых популящий так и поколений, в общем варьировал в пределах 8,10-8,30 голов. Использование индексной оченки животных и анализ различных схем их скрещивания позволяет утверждать, что максимальные показатели живой массы имели потомки животных, селекционные индексы которых для самцов составляли не ниже 60 баллов, самок - 55 баллов соответственно, что следует учитывать при планировании селекционной работы с популяциями.

Ключевые слова: кролики, живая масса, стати тела, мясная продуктивность воспроизводительная способность, селекционные индексы

Вступ. Вирощування кролів за промислової технології утримання вимагає кропіткої роботи кролівників 3 поголів'ям, яка базується на знаннях характеру успадкування селекційних ознак та рівня їх реалізації в системі «генотип-середовище». Удосконалення селекційної роботи у сучасному кролівництві з метою точного визначення племінної цінності вимагає використання сучасних селекційно-генетичних методів, які разом із комплексним бонітуванням включають в себе визначення рівня мінливості селекційних ознак для забезпечення максимального рівня фенотипової консолідації поголів'я за показником м'ясної продуктивності $[1,2$, $8,9,10]$.

Нині у племінній роботі вітчизняного кролівництва використовуються такі методи, як оцінка тварин за якістю нащадків, розведення тварин за лініями та родинами. Проте визначення племінної цінності кролів проводиться лише по фенотипу при бонітуванні. При цьому виходять з оцінки кролів за породністю, за розвитком живої маси та тілобудови, за густиною 
і забарвленню волосяного покриву, а також за відтворювальною здатністю. Основним залишається метод, який зводиться на визначенні походження та індивідуальних якостей кролів, проте характеризується невисокою точністю [2].

Таким чином, основна увага в племінній роботі сучасного кролівництва має бути направлена на визначенні генетичних та економічних параметрів тварин, конструюванні селекційних індексів, метою яких є підвищення ефективності та здешевлення ведення селекції $[2,10]$. Визначення популяційно-генетичних параметрів тварин з метою подальшої розробки селекційних індексів визначення племінної цінності кролів є актуальним питанням галузі. Тому, значна увага в племінній роботі сучасного кролівництва має бути направлена на визначення генетичних та економічних параметрів тварин, конструюванні селекційних індексів, метою яких $є$ підвищення ефективності та здешевлення ведення селекції. Визначення популяційно-генетичних параметрів кролів різних вітчизняних та зарубіжних порід з використанням селекційних індексів визначення племінної цінності кролів є безсумнівно актуальною.

Метою дослідження є дослідити рівень продуктивності кролів різних порід та ефективність використання селекційних індексів в кролівництві.

Матеріал та методи досліджень. Дослідження м'ясної продуктивності кролів проводили в Черкаській області на базі кролеферм СГ ПП «Марчук Н.В.» та дослідній кролефермі Черкаської дослідної станції біоресурсів НААН на поголів'ї кролів каліфорнійської, новозеландської білої порід та полтавське срібло за промислової технології утримання.

Екстерєрні показники кролів визначалася під час бонітування згідно інструкції [5]. Успадковуваність селекційно-генетичних ознак кролів різних порід визначали методами подвоєння коефіцієнтів кореляції шляхом «мати-дочка» $\left(h^{2}=2 r\right)$ [7].

Селекційний індекс з використанням генетичних параметрів розраховували за формулою:

$$
\mathrm{I}=\mathrm{h}_{1} \mathrm{Mn}-\mathrm{h}_{2} \mathrm{M} \text { зк }+\mathrm{h}_{3} \text { Ммпт }
$$

де $\mathrm{Mn}$ - велечина середньодобового приросту живої маси нащадків, отриманої від перевіряємого самця в період 45-90 днів;

Мзк - велечина затрат корму на одиницю приросту нащадків, отриманих від перевіряємого самця в період 45-90 днів;

Ммпт - середня маса парної тушки молодняка, отриманого від перевіряємих самців у віці 90 днів;

$\mathrm{h}_{1}, \mathrm{~h}_{2}, \mathrm{~h}_{3}-$ коефіцієнти спадковості за цими ознаками [6].

Одержані матеріали наукових досліджень оброблялися методами математичної статистики засобами програмного пакету «Statistica - 6.1» та Excel (Microsoft Office 2010) у середовищі Windows на ПЕОМ за алгоритмами Н.А. Плохинського [8].

Результати досліджень. Досліджуючи параметри розвитку кролів різних порід встановлено, що за показниками живої маси у віці 4-х місяців на момент проведення дослідження перевагу над аналогами мали кролі новозеландської білої породи, середнє значення живої маси яких становило 2,85 кг, що на 0,27 кг вище аналогічного показника по групі тварин вітчизняної селекції та на 0,12 кг вище порівняного з кролями породи каліфорнійська $(\mathrm{P}>0,999)$ (табл. 1).

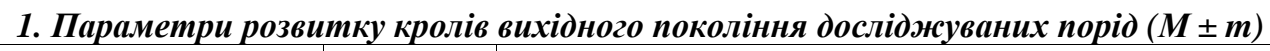

\begin{tabular}{|l|c|c|c|c|}
\hline \multirow{2}{*}{\multicolumn{1}{|c|}{ Показник }} & \multirow{2}{*}{} & \multicolumn{3}{|c|}{ Порода кролів } \\
\cline { 3 - 5 } & & новозеландська біла & каліфорнійська & полтавське срібло \\
\hline Жива маса, г & 100 & $2850 \pm 14,2 * * *$ & $2730 \pm 12,3$ & $2580 \pm 13,7$ \\
\hline Пряма довжина тулуба, см & 100 & $51,5 \pm 0,51$ & $52,5 \pm 0,81$ & $54,1 \pm 0,52 * * *$ \\
\hline Обхват тулуба, см & 100 & $34,15 \pm 0,9 * *$ & $31,5 \pm 0,10$ & $31,15 \pm 0,11$ \\
\hline Коса довжина тулуба, см & 100 & $26,4 \pm 0,8$ & $24,3 \pm 0,9$ & $27,6 \pm 0,15 * * *$ \\
\hline Індекс збитості, \% & 100 & $66,3 \pm 1,97 * *$ & $62,2 \pm 2,13$ & $56,2 \pm 1,78$ \\
\hline
\end{tabular}

Примітка: ** - $>$ > 0,99, *** - P > 0,999 до аналогічного показнику по групах. 
За такою ознакою як пряма довжина тулуба максимальне значення зареєстровано по групі кролів полтавське срібло - 54,1 cм. Переважання яких над тваринами аналогами решти порід склало відповідно 1,6 та 2,6 см. Мінімальним показник зареєстровано по групі тварин новозеландської білої породи (Р > 0,999).

Оцінка показнику обхвату тулуба дає змогу стверджувати, що за даною ознакою переважали кролі новозеландської білої породи - 34,2 см, а мінімальним воно було у кролів вітчизняної породи - 31,2 см (Р>0,99). За показником косої довжини тулуба спостерігалася аналогічна ситуація - максимальні значення досліджуваного показнику зареєстровано по групі тварин полтавське срібло - 27,6 см (Р > 0,999).

Розрахований на основі вимірювання статей тіла індекс збитості свідчить про вищу м'ясну продуктивність кролів м'ясного напряму селекції новозеландська біла та каліфорнійська, розраховані коефіцієнти по групах яких становила 62-66 \%, що на 6 та 10\% вище аналогічного показника по досліджуваній групі кролів породи полтавське срібло $(\mathrm{P}>0,999)$.

В розрізі поколінь спостерігається тенденція до зниження показників м'ясної продуктивності у таких порід кролів як новозеландська біла та полтавське срібло (Р > 0,999) (табл. 2).

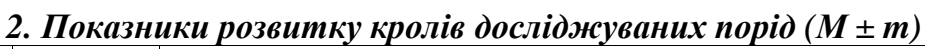

\begin{tabular}{|c|c|c|c|c|}
\hline \multirow{2}{*}{ Показник } & \multirow{2}{*}{$\mathrm{n}$} & \multicolumn{3}{|c|}{ Порода кролів } \\
\hline & & новозеландська біла & каліфорнійська & полтавське срібло \\
\hline Жива маса, г & 100 & $2650 \pm 13,52$ & $2810 \pm 11,03 * * *$ & $2430 \pm 12,84$ \\
\hline Пряма довжина тулуба, см & 100 & $49,5 \pm 0,42$ & $53,4 \pm 0,83$ & $54,5 \pm 0,32$ \\
\hline Обхват тулуба, см & 100 & $33,2 \pm 0,93$ & $30,5 \pm 0,14$ & $29,75 \pm 0,11$ \\
\hline Коса довжина тулуба, см & 100 & $26,4 \pm 0,81$ & $25,3 \pm 0,12$ & $25,8 \pm 0,17$ \\
\hline Індекс збитості, \% & 100 & $64,2 \pm 1,50$ & $64,2 \pm 2,13$ & $54,8 \pm 1,75$ \\
\hline
\end{tabular}

Примітка: *** - P > 0,999 до аналогічного показнику по групах.

По групі кролів новозеландської білої породи відмічено зниження середнього значення на $12 \%$ за показником прямої дожини тулуба $(\mathrm{P}>0,999)$, мінімальне $(2,9 \%)$ - за показником обхвату тулуба $(\mathrm{P}<0,95)$. По групі кролів породи полтавське срібло максимальне зниження спостерігалося за показником косої довжини тулуба (7,0\%), який у тварин другого покоління дорівнював 25,8 cм (Р>0,999). У кролів породи каліфорнійська зниження середнього значення показника зареєстровано лише за показником обхвату тулуба (на 3\%). За рештою ознак у кролів цієї породи спостерігалося підвищення середнього значення показників на 1,8-4\%.

Результати дослідження відтворювальної здатності кролематок досліджуваних порід наведено в таблиці 3. Дані свідчать про високий рівень показнику плідності самок незалежно від породи. Показник заплідненості кролематок знаходився в межах 76-91\%. При цьому мінімальна заплідненість була у кролів новозеландської білої породи, а максимальна - у тварин каліфорнійської породи кролів.

Показник плідності кролематок піддавався мінливості як всередині груп так і між породами. Для кролів новозеландської білої породи даний показник варіював в межах 8,10-8,30 голів, при цьому максимальним даний показник був встановлений у кролематок другого покоління $(\mathrm{P}<0,95)$. Порівнюючи результати окролів за групою кролів каліфорнійської породи встановлено аналогічну тенденцію: рівень плідності кролематок другого покоління був вищим на 0,55 гол. $(\mathrm{P}>0,95)$.

Аналіз результатів показників відтворювальної здатності кролематок породи полтавське срібло засвідчив про зниження рівня плідності самок другого покоління. Втім середні значення плідності кролематок даної породи також характеризувалися високими показниками і знаходились на рівні 7,5-7,9 голів. При порівнянні середніх значень встановлена різниця виявилася невірогідною $(\mathrm{P}<0,95)$.

Частка елімінації молодняку кролів породи новозеландська біла склала 22,9-27,2\%, по групі кролів каліфорнійської породи - 24,9-28,3\%, полтавське срібло - 16,4-25,3. 


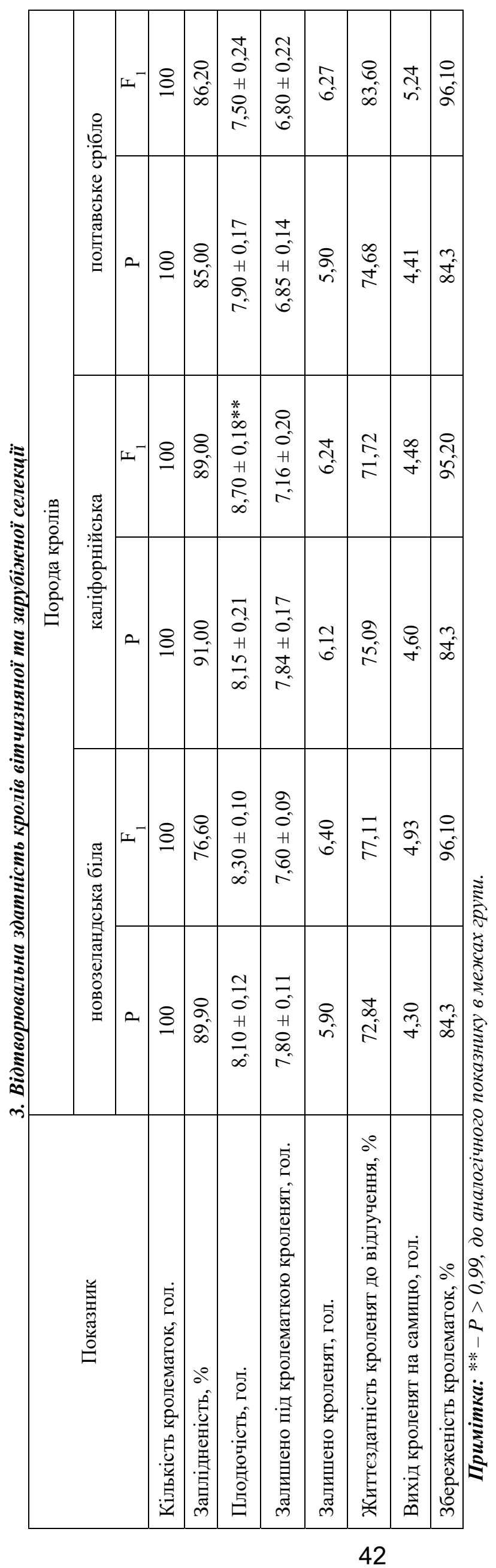


Результати вивчення індексної оцінки плідників і кролематок наведено в таблиці 4. Селекційні індекси самців та самок кролів свідчать, що плем'ядро досліджуваних популяцій складають тварини з індексом 50-70 балів. Варто зазначити, що кількість самців, які брали участь в оцінці становила по 10 голів в кожній групі. Серед оцінених плідників новозеландської білої породи, переважна кількість самців мали оцінку 66-70 балів (40\%), для групи плідників каліфорнійської породи 40\% самців були оцінені в 50-55 балів, у тварин породи полтавське срібло 80\% плідників були оцінені в 56-65 балів.

4. Розподіл «плем'ядра» популяції кролів досліджуваних порід за селекційними індексами, \%

\begin{tabular}{|c|c|c|c|c|c|}
\hline \multirow{2}{*}{ Порода } & \multicolumn{4}{|c|}{ Селекційний індекс, бали } & \multirow{2}{*}{ Разом } \\
\hline & $50-55$ & $56-60$ & $61-65$ & $66-70$ & \\
\hline \multicolumn{6}{|c|}{ Самці } \\
\hline Новозеландська біла & 30,0 & 20,0 & 10,0 & 40,0 & 100 \\
\hline Каліфорнійська & 40,0 & 20,0 & 10,0 & 30,0 & 100 \\
\hline Полтавське срібло & 0,0 & 40,0 & 40,0 & 20,0 & 100 \\
\hline \multicolumn{6}{|c|}{ Самки } \\
\hline Новозеландська біла & 34,0 & 22,0 & 22,0 & 22,0 & 100 \\
\hline Каліфорнійська & 26,0 & 34,0 & 16,0 & 24,0 & 100 \\
\hline Полтавське срібло & 22,0 & 36,0 & 28,0 & 14,0 & 100 \\
\hline
\end{tabular}

Оскільки кількість плідників менша за кількість самок, які використовувалися для розмноження, відповідно вимоги до них висувалися кролівниками значно вищі ніж до самок, що мало в свою чергу відображення на результатах індексної оцінки. Розподіл кролематок вихідного покоління виявися майже рівномірним за всіма чотирма категоріями. У самок новозеландської породи максимальну частку тварин (34 \%) склали кролематки індекс оцінки яких знаходився в межах 50-55 балів, за рештою категорій спостерігався рівномірний розподіл за балами - по 22 \%. Для самок каліфорнійської породи, як і для кролів породи полтавське срібло переважна кількість тварин мали оцінку за використаним селекційним індексом 56-60 балів.

На основі проведення оцінки генотипів кролематок і самців (плем'ядро) по селекційним індексам проводили їх поєднання з ціллю вивчення різних типів підбору по величині індексу племінної цінності за наступною схемою (табл. 5).

Аналіз показників живої маси кролів у віці 120 днів, отриманих від зазначених типів схрещувань, свідчить, про тенденцію до зростання даного показника за використання батьків за схемою ВхС та СхС. Зокрема, наведені дані свідчать, що по групі кролів новозеландської білої породи максимальні показники живої маси мали нащадки при поєднанні пар за гетерогенною схемою (самки з індексом 61-65 балів та всі задіяні самці). За такого варіанту середня жива маса становила 2820-2859 г, що, в свою чергу, вище на 86-125 г мінімального значення, яке отримано при схрещуванні кролів з індексами 50-55 балів (Р $>0,95 \ldots 0,999)$. Для кролів каліфорнійської породи максимальні середні значення показнику живої маси нащадків зареєстровано при використанні схеми схрещування $\mathrm{CxB}, \mathrm{CxC}, \mathrm{DxC}$ та $\mathrm{DxD}(\mathrm{P}>0,95 \ldots 0,999)$.

Наші дані свідчать, що використання крупного самця на дрібніших самках забезпечує отримання потомства з вищою живою масою за умови, що ці самки мають селекційний індекс вище 55 балів. При порівнянні з самками групи А різниця склала 87 г, мінімальне ж значення досліджуваного показнику отримано за схеми поєднання пар AхA - 2710 г, що вірогідно нижче максимального показнику на 150 г (Р > 0,95).

По групі кролів породи полтавське срібло спостерігається аналогічна тенденція - максимальні значення живої маси мають нащадки, отримані від поєднання крупних самців як за гомогенного, так і гетерогенного добору (BxC,D, CxB-D), значення живої маси нащадків яких виявилися вірогідно вищими порівняно з тваринами, отриманими при інших типах добору $(\mathrm{P}>0,95 \ldots 0,99)$. 
5. Схема поєднання пар кролів досліджуваних порід та жива маса нащадків у віці 120 днів

\begin{tabular}{|c|c|c|c|c|c|c|c|c|c|}
\hline \multirow{3}{*}{$\begin{array}{l}\frac{\pi}{4} \\
\frac{0}{0} \\
\frac{0}{0}\end{array}$} & \multirow{3}{*}{$\begin{array}{c}\text { Величина } \\
\text { індекса } \\
\text { самця, ба- } \\
\text { лів }\end{array}$} & \multicolumn{4}{|c|}{$\begin{array}{l}\text { Величина індекса самиці/ } \\
\text { схема схрещування }\end{array}$} & \multicolumn{4}{|c|}{$\begin{array}{c}\text { Середня жива маса нащадків кролів за різних типів } \\
\text { схрещувань, г }\end{array}$} \\
\hline & & A & B & $\mathrm{C}$ & $\mathrm{D}$ & \multirow{2}{*}{ I } & \multirow{2}{*}{ II } & \multirow{2}{*}{ III } & \multirow{2}{*}{ IV } \\
\hline & & I & II & III & IV & & & & \\
\hline \multirow{4}{*}{ 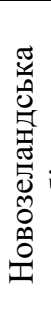 } & $\begin{array}{c}\mathrm{A} \\
50-55\end{array}$ & $\mathrm{AxA}$ & $\mathrm{AxB}$ & $\mathrm{AxC}$ & $\mathrm{AxD}$ & $2734 \pm 11,4$ & $2746 \pm 14,8$ & $2850 \pm 12,1^{* * *}$ & $\begin{array}{c}2855 \pm 14,7 * * \\
*\end{array}$ \\
\hline & $\begin{array}{c}\mathrm{B} \\
56-60\end{array}$ & $\mathrm{BxA}$ & $\mathrm{BxB}$ & $\mathrm{BxC}$ & $\mathrm{BxD}$ & $2818 \pm 9,2 * * *$ & $2846 \pm 17,2 * * *$ & $2859 \pm 15,7 * * *$ & $2741 \pm 14,2$ \\
\hline & $\begin{array}{c}\mathrm{C} \\
61-65\end{array}$ & $\mathrm{CxA}$ & $\mathrm{CxB}$ & $\mathrm{CxC}$ & $\mathrm{CxD}$ & $2812 \pm 17,4^{* *}$ & $2750 \pm 18,9$ & $2855 \pm 19,9^{* * *}$ & $\begin{array}{c}2845 \pm 21,4^{* *} \\
*\end{array}$ \\
\hline & $\begin{array}{c}\mathrm{D} \\
66-70\end{array}$ & DxA & $\mathrm{BxB}$ & $\mathrm{DxC}$ & DxD & $2813 \pm 16,4$ & $2784 \pm 15,3$ & $2820 \pm 18,4$ & $\begin{array}{c}2850 \pm 10,1^{* *} \\
* *\end{array}$ \\
\hline \multirow{4}{*}{ 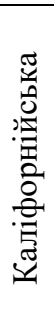 } & $\begin{array}{c}\text { A } \\
50-55\end{array}$ & $\mathrm{AxA}$ & $\mathrm{AxB}$ & $\mathrm{AxC}$ & $\mathrm{AxD}$ & $2710 \pm 21,4$ & $2750 \pm 14,2$ & $2800 \pm 27,1^{* *}$ & $2790 \pm 18,5^{* *}$ \\
\hline & $\begin{array}{c}\mathrm{B} \\
56-60\end{array}$ & $\mathrm{BxA}$ & $\mathrm{BxB}$ & $\mathrm{BxC}$ & $\mathrm{BxD}$ & $2750 \pm 17,4$ & $2810 \pm 16,7^{* *}$ & $2820 \pm 19,5^{* *}$ & $2815 \pm 16,5^{* *}$ \\
\hline & $\begin{array}{c}\mathrm{C} \\
61-65\end{array}$ & $\mathrm{CxA}$ & $\mathrm{CxB}$ & $\mathrm{CxC}$ & $\mathrm{CxD}$ & $2765 \pm 18,4$ & $2852 \pm 16,4 * * *$ & $2860 \pm 18,3 * * *$ & $2820 \pm 11,4 * *$ \\
\hline & $\begin{array}{c}\mathrm{D} \\
66-70 \\
\end{array}$ & DxA & $\mathrm{BxB}$ & $\mathrm{DxC}$ & DxD & $2820 \pm 15,7^{* *}$ & $2760 \pm 15,3$ & $2840 \pm 14,2 * * *$ & $\begin{array}{c}2830 \pm 14,8^{* *} \\
*\end{array}$ \\
\hline \multirow{4}{*}{ 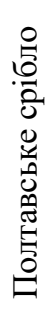 } & $\begin{array}{c}\mathrm{A} \\
50-55\end{array}$ & $\mathrm{AxA}$ & $\mathrm{AxB}$ & $\mathrm{AxC}$ & $\mathrm{AxD}$ & $2430 \pm 21,4$ & $2510 \pm 14,8^{* * *}$ & $2495 \pm 15,4^{* *}$ & $2500 \pm 21,1 * *$ \\
\hline & $\begin{array}{c}\mathrm{B} \\
56-60\end{array}$ & $\mathrm{BxA}$ & $\mathrm{BxB}$ & $\mathrm{BxC}$ & $\mathrm{BxD}$ & $2480 \pm 21,7$ & $2490 \pm 17,9$ & $2560 \pm 18,7^{* *}$ & $2540 \pm 17,8^{* *}$ \\
\hline & $\begin{array}{c}\mathrm{C} \\
61-65\end{array}$ & $\mathrm{CxA}$ & $\mathrm{CxB}$ & $\mathrm{CxC}$ & $\mathrm{CxD}$ & $2520 \pm 22,3$ & $2610 \pm 20,3^{* *}$ & $2585 \pm 20,4^{* *}$ & $2574 \pm 19,3$ \\
\hline & $\begin{array}{c}\mathrm{D} \\
66-70\end{array}$ & DxA & $\mathrm{BxB}$ & $\mathrm{DxC}$ & DxD & $2470 \pm 19,5$ & $2530 \pm 23,4^{*}$ & $2520 \pm 22,6$ & $2490 \pm 15,3$ \\
\hline
\end{tabular}

Примітка: *-P>0,95, ** - ${ }^{*}>0,99, * * *-P>0,999$ до аналогічного показнику в межах групи.

\section{Висновки.}

1. Напрям селекції досліджуваних порід засвідчив наявність різниці за показниками продуктивності кролів. Дослідження статей тіла свідчить, про вищі значення показників, які визначають м'ясну продуктивність у спеціалізованих м'ясних порід, були у кролів новозеландська біла та каліфорнійська порівняно з вітчизняною (полтавське срібло).

2. Використання індексної селекції надає змогу провести ефективний підбір тварин за показником живої маси та розробляти дієві схеми підбору пар базуючись на об'єктивну оцінку тварин, що використовуються для розмноження.

3. Використання методів індексної оцінки продуктивних ознак дозволяє об'єктивно виділити плідників та кролематок для формування високопродуктивної популяції кролів за ознакою живої маси.

4. Максимальні показники живої маси мали нащадки тварин, селекційні індекси яких для самців становили не нижче 60 балів, самок - 55 балів відповідно, що слід враховувати при плануванні селекційної роботи з популяціями кролів.

\section{БІБЛІОГРАФІЯ}

1. Гончар, О. Ф. Відтворювальна здатність кролематок новозеландської білої породи різних екстер'єрних типів/ О. Ф. Гончар, Є. А. Шевченко, О. М. Гавриш//Вісник центру наукового забезпечення АПВ Харківської області. - 2013. - Вип. 14. - С. 185-189.

2. Гончар, О. Ф. Генетична оцінка підвищення м`ясної продуктивності кролів новозеландської білої породи на різних етапах постнатального онтогенезу / О. Ф. Гончар, Є. А. Шевченко// Вісник Черкаського інституту агропромислового виробництва : міжвід. темат. зб. наук. праць, Черкаси, 2011. - Вип. 11. - С. 108-112. 
3. Гончар, О. Ф.Визначення племінної цінності кролів новозеландської білої породи з використанням індексної селекції / О. Ф. Гончар, Є. А. Шевченко., О. М. Гавриш // Вісник центру наукового забезпечення АПВ Харківської області. - 2012. - Вип. 12. - С. 300-306.

4. Гончар, О. Ф. Індексна оцінка племінної цінності кролів : (методичні рекомендації)/ О. Ф. Гончар, С. А. Шевченко, О. М. Гавриш/ Черкаська дослідна станція біоресурсів Інституту розведення і генетики тварин НААН. - Черкаси, 2012. - 20 с.

5. Інструкція з бонітування норок, лисиць, песців, тхорів, єнотовидних собак, нутрій кліткового розведення. Інструкція з бонітування кролів. Інструкція з ведення племінного обліку в звірівництві та кролівництві : нормативне виробничо-практичне видання : затвер. наказом М-ва аграр. політики України 25.09.2003 № 351 / авт. кол. : Ю.Ф. Мельник, Д. М. Микитюк, А. М. Литовченко, В. П. Буркат, О. В. Білоус, Н. В. Кудрявська, О. О. Чорна, І. С. Вакуленко, В. I. Міхно ; М-во аграр. політики України, Укр. акад. аграр. наук, Держ. наук.-вироб. концерн "Селекція", Ін-т тваринництва УААН. - К. : П.П. "Бланк-Сервіс", 2003. - 87 с.

6. Пат. 71714 Україна, МПК А 01 К 67/00. Спосіб визначення племінної цінності кролів різних генотипів із використанням селекційно-генетичного індексу / Бащенко М. І., Гончар О. Ф., Шевченко С. А. ; заявник і патентовласник Черкаська дослідна станція біоресурсів Інституту розведення і генетики НААН України. - № u 2011 15708; заявл. 30.12.2011; опубл. 25.07.2012, Бюл. № 14.

7. Племінна робота : довідник / за ред. : М. В. Зубця, М. З. Басовського. - К. : Асоц. «Україна». - 1995. - $440 \mathrm{c.}$

8. Плохинский, Н. А. Руководство по биометрии для зоотехников / Н. А. Плохинський. - М. : Колос, 1969. -255 с.

9. Khalil, M. H. Methods criteria, techeniques, and genetic responsees for rabbit selection : proc 9th World Rabbit Congress / M. H. Khalil, M. H. Khalil, A. M. Ali.-Saef. - Italy, Verona, 2008. P. 1-22.

10. Piles, M. The effect of selection for growth rate on carcass composition and meat characteristics of rabbits / M. Piles, A. Blasco, M. Pla // Meat Science - 2005. - Vol. 54, № 9. - P. 347-355.

11. Metzger, Sz. A study of the carcass traits of different rabbit genotypes / Sz. Metzger, M. Odematt, Zs. Szendro, M. Mohaupt, R. Romvari // World Rabbit Sciense. - 2006. - № 14. - P. 107-114.

\section{REFERENCES}

1. Honchar, O. F., Ye. A. Shevchenko, and O. M. Havrysh. 2013. Vidtvoryuvalna zdatnist krolematok novozelandskoyi biloyi porody riznykh ekster'yernykh typiv - Reproductive capacity of New Zealand white breeds of various exterior types. Visnyk tsentru naukovoho zabezpechennya APV Kharkivskoyi oblasti - Bulletin of the Center of Scientific Supply of Aviation of the Kharkiv Region. 14:185-189 (in Ukrainian).

2. Honchar, O. F., Ye. A. Shevchenko. 2011. Henetychna otsinka pidvyshchennya m'yasnoyi produktyvnosti kroliv Novozelandskoyi biloyi porody nariznykh etapakh postnatalnoho ontohenezu - Genetic evaluation of the increase in the productivity of New Zealand rabbit rabbits in different stages of postnatal ontogenesis. Visnyk Cherkaskoho instytutu ahropromyslovoho vyrobnytstva - Bulletin of the Cherkasy Institute of Agricultural Production. 11:108-112 (Ukrainian).

3. Honchar, O. F., Ye. A. Shevchenko, and O. M. Havrysh. 2012. Vyznachennya pleminnoyi tsinnosti kroliv Novozelandskoyi biloyi porody $\mathrm{z}$ vykorystannyam indeksnoyi selektsiyi Determination of breeding value of rabbits of New Zealand white breed using indecent selection. Visnyk tsentru naukovoho zabezpechennya APVK harkivskoyi oblasti - Bulletin of the Center of Scientific Supply of Aviation of the Kharkiv Region. 12:300-306 (Ukrainian).

4. Honchar, O. F., Ye. A. Shevchenko, and O.M. Havrysh. 2012. Indeksna otsinka pleminnoyi tsinnosti kroliv (metodychni rekomendatsiyi). Cherkaska doslidna stantsiya bioresursiv Instytutu rozvedennya ta henetyky tvaryn NAAN Cherkasy - Cherkasy Experimental Station of Bioresources of the Institute of Animal Breeding and Genetics, NAAS of Ukraine. Cherkasy, 20 (Ukrainian). 
5. Melnyk, Yu. F., D. M. Mykytiuk, A. M. Lytovchenko, V. P. Burkat, O. V. Bilous, N. V. Kudriavska, O. O. Chorna, I. S. Vakulenko, and V. I. Mikhno. 2003. Instruktsiia z bonituvannia norok, lysyts, pestsiv, tkhoriv, yenotovydnykh sobak, nutrii klitko-voho rozvedennia. Instruktsiia $\mathrm{z}$ bonituvannia kroliv. Instruktsiia $\mathrm{z}$ vedennia pleminnoho obliku $v$ zvirivnytstvi ta krolivnytstvi : normatyvne vyrobnycho-praktychne vydannia : zatver. nakazom $M$-va ahrar. polityky Ukrainy 25.09.2003 № 351 - Instructions for boning of mink, foxes, foxes, ferrets, raccoon dogs, infectious cellulose breeding. Manual for boning rabbits. Instruction on keeping breeding records in animal breeding and rabbing: normative production and practical edition: approved by the order of the Ministry of Agrarian Policy of Ukraine dated September 25, 2003 № 351. Ministerstvo ahrarnoi polityky Ukrainy, Ukrainska akademiia ahrarnykh nauk, Derzhavnyi naukovo-vyrobnychyi kontsern "Selektsiia", Instytut tvarynnytstva UAAN. P.P. "Blank-Servis" - Ministry of Agrarian Policy of Ukraine, Ukrainian Academy of Agrarian Sciences, State Research and Production Concern "Selection", Institute of Animal Husbandry of UAAS. P.P. Blank-Service. Kyiv, 87 (Ukrainian).

6. Bashchenko, M. I., M. I. Bashchenko, O. F. Honchar, and Ye. A. Shevchenko. Pat. 71714 Ukrayina, MPK A $01 \mathrm{~K}$ 67/00. Sposib vyznachennya pleminnoyi tsinnosti kroliv riznykh henotypiv z vykorystannyam selektsiyno-henetychnoho indeksu - A method for determining the breeding value of rabbits of different genotypes using the selective genetic index. Zayavnyk i patentovlasnyk Cherkaska doslidna stantsiya bioresursiv Instytutu rozvedennya ta henetyky NAAN Ukrayiny - Applicant and Patent Owner Cherkasy Experimental Station for Bioresources at the Institute of Breeding and Genetics of the National Academy of Sciences of Ukraine. - № u 2011 r. 15708; zayavl. 30.12.2011; opubl. 25.07.2012, Byul. № 14 (Ukrainian).

7. Zubets, M. V., and M. Z. Basovskiy. 1995. Pleminna robota. Dovidnyk - Tribal work. Directory. Kyiv, Asots. «Ukrayina». 291-322 (Ukrainian).

8. Plokhynskyy, N. A. 1969. Rukovodstvo po biometry dlya zootekhnykov - Leadership for zootechnicians in biometrics. - Moscow, Kolos, 255 (in Russian).

9. Khalil, M. H., M. H. Khalil, and A. M. Ali.-Saef. 2008. Methods criteria, techeniques, and genetic responsees for rabbit selection : review. In Proc 9th World Rabbit Congress. Italy, Verona, 122 (in English).

10. Piles, M., M. Piles, A. Blasco, and M. Pla. 2005. The effect of selection for growth rate on carcass composition and meat characteristics of rabbits. Meat Science. 54(9):347-355 (in English).

11. Metzger, Sz. Sz. Metzger, M. Odematt, Zs. Szendro, M. Mohaupt, and R. Romvari. 2006. A study of the carcass traits of different rabbit genotypes. World Rabbit Sciense. (14):107-114 (in English).

УДК 636.2.034.082(497.2)

\title{
МОЛОЧНОЕ СКОТОВОДСТВО В БОЛГАРИИ - КОМПЛЕКСНАЯ ОЦЕНКА
} МОЛОЧНЫХ ФЕРМ

\author{
В. М. ГАЙДАРСКА ${ }^{1}$, М. М. ИГНАТОВА ${ }^{1}$, ЦВ. Х. МЕТОДИЕВА ${ }^{1}$, П. И. ЛЮЦКАНОВ ${ }^{2}$ \\ ${ }^{1}$ Институт животноводных наук (Костинброд, Республика Болгария) \\ ${ }^{2}$ Научно-практический институт биотехнологии в зоотехнии и ветеринарной медицинь \\ (Максимовка, Республика Молдова) \\ wgaidarska@mail.bg
}

Молочное скотоводство является традииионной отраслью и остается одной из основных в сельском хозяйстве Болгарии. Целью наших исследований явилось динамика изменения в молочном скотоводстве с 2007 по 2018 г2., включая: общее производство молока, число 